\title{
ETNICIDADE, POLÍTICA E ASCENSÃO SOCIAL: UM EXEMPLO TEUTO-BRASILEIRO
}

Giralda Seyferth

A imigração alemã teve um papel relevante no processo de colonização de diversas regiões do sul do Brasil desde 1824, quando o governo imperial fundou a colônia de São Leopoldo, no Rio Grande do Sul. No contexto de ocupação do território mediante a colonização baseada na pequena propriedade familiar - da qual participaram os imigrantes de origem germânica -, os processos de diferenciação interna, formação de classes e ascensão social aconteceram juntamente com a cristalização da identidade étnica teuto-brasileira, ancorada na especificidade cultural e no jus sanguinis, em contraste com os imperativos da assimilação ditados pelo nacionalismo brasileiro como condição da cidadania. O desenvolvimento econômico, em especial a industrialização de alguns núcleos coloniais, ajudou a dar visibilidade ao grupo étnico teuto-brasileiro. $O$ presente artigo irá enfatizar a questão da mobilidade social nos campos econômico e político, e os problemas associados a sentimentos de etnicidade, focalizando trajetórias de ascensão social no início do processo de industrialização de uma região identificada com a imigração alemã - o Vale do Itajaí (SC).

\section{A colonização do Vale do Itajaí}

A primeira colônia alemã de Santa Catarina foi fundada em 1829, em área relativamente próxima à capital Desterro (Florianópolis), com a denominação de São Pedro de Alcântara; na mesma época, colonos alemães instalaram-se em M afra, próximo à fronteira com o Paraná.

Essas e outras iniciativas de colonização na primeira metade do século XIX não produziram os resultados desejados (a implementação da agricultura familiar e a ocupação de terras devolutas) uma vez que o número de imigrantes assentados era pouco significativo e nem todos permane- 
ceram nas colônias. Em 1835, o governo provincial promoveu o reassentamento de algumas famílias alemãs egressas de São Pedro de Alcântara em dois núcleos (Pocinho e Belchior) localizados no baixo rio Itajaí-açu (em área hoje pertencente ao município de Gaspar). Foi a primeira tentativa de colonização no Vale do Itajaí - região considerada como "vazio" demográfico, em grande parte inexplorada e possível rota de acesso ao planalto - de certa forma provocada pelo descontentamento dos colonos em relação ao projeto de São Pedro de Alcântara ${ }^{1}$.

A segunda colônia surgiu em 1846 como empreendimento particular: o engenheiro e major Charles Van Lede formou a Companhia BelgoBrasileira de Colonização, empresa que adquiriu terras de um grande proprietário de Itajaí para assentar imigrantes oriundos da Bélgica. Embora situada em área próxima à foz do rio Itajaí-açu, no seu trecho navegável, a colônia belga de llhota fracassou. Em meados do século XIX apenas 60 famílias - alemãs, belgas e brasileiras - permaneciam nos arraiais de Pocinho e Belchior.

A colonização sistemática do Vale do Itajaí, na verdade, começou em 1850, com a fundação de uma segunda colônia particular, na confluência do ribeirão da Velha com o rio Itajaí-açu - ponto a partir do qual este deixa de ser navegável. A pós uma longa negociação com os governos provincial e imperial, Hermann Blumenau² formou uma empresa colonizadora que obteve uma concessão de terras devolutas destinada à ocupação com imigrantes alemães em regime de pequena propriedade familiar. Coincidentemente, os primeiros colonos chegaram à região poucos dias antes da promulgação da Lei de Terras (Lei 601, de 18/9/1850)3. Esse projeto, apesar das dificuldades encontradas por Hermann Blumenau para trazer imigrantes, deu impulso à colonização alemã na província de Santa Catarina. Uma outra colônia particular - D. Francisca, depois J oinville - surgiu em 1851 nas terras devolutas do noroeste de Santa Catarina recebidas como dote pela princesa D. Francisca, irmã de Pedro II, quando do seu casamento com o príncipe de J oinville. Para a implementação dessa colônia constituiu-se a Sociedade Colonizadora Hamburguesa, que destinou uma área de 46.582 hectares para assentamento de alemães, suíços e noruegueses. Quase uma década depois, em 1860, começou o povoamento do principal afluente do Itajaí-açu, com a fundação da colônia Itajaí (Brusque), administrada pelo estado; nesse mesmo ano, o governo imperial assumiu a administração da colônia de Blumenau, naquele momento um empreendimento ameaçado por dificuldades financeiras 4 . Isto não produziu um retraimento nas iniciativas particulares: J oinville seguiu como empreendimento privado durante 
todo o período de assentamentos, e empresas particulares organizaram a ocupação de diversas áreas, inclusive o alto Vale do Itajaí (onde a Sociedade Colonizadora Hanseática fundou uma das últimas colônias alemãs da região - Hammonia (Ibirama) - , em 1899).

De fato, não importa muito se as colônias eram particulares ou oficiais, pois o modelo de ocupação era um só para todas: visava a implementação de um sistema fundiário que privilegiava a pequena propriedade familiar, recebida por compra, a prazo, em terras públicas, sob controle da legislação e do M inistério da A gricultura. O objetivo principal era o povoamento do território com pequenos produtores rurais, preferencialmente imigrantes europeus.

O Vale do Itajaí é um exemplo característico da política imigratória voltada para a colonização. Ao iniciar a ocupação sistemática, em 1850, excetuando as famílias remanescentes dos projetos de 1835 e 1846, além de pequenos grupos indígenas, havia apenas alguns posseiros, cuja principal atividade era a extração de madeira, mesmo assim na região mais próxima à vila de Itajaí. Nas duas principais colônias - Brusque e Blumenau - os primeiros imigrantes chegaram pelo rio e, coincidência ou não, fixaram o núcleo inicial justamente no ponto onde os rios Itajaí-mirim e Itajaí-açu deixam de ser navegáveis. Os colonos não encontraram lotes demarcados, dificultando os assentamentos - situação que se prolongaria por quase toda a segunda metade do século XIX, motivada pela crônica falta de recurso das administrações oficiais. $\mathrm{Na}$ prática, as demarcações de linhas e lotes, bem como a abertura das primeiras vias de comunicação com Itajaí, foram realizadas usando os colonos como mão-deobra. A espera pela concessão de um lote podia variar de seis meses a um ano, deixando os imigrantes dependentes dos subsídios oficiais (depois incorporados à dívida colonial) e do crédito dos comerciantes locais (que forneciam mantimentos e equipamentos). Estes fatos mostram a precariedade com que a ocupação foi realizada e dimensionam uma realidade que, mais tarde, seria acionada como símbolo étnico, o pioneirismo dos alemães, os primeiros ocupantes da região, e a eficácia do seu trabalho.

A demarcação dos lotes ocorreu a partir de picadas abertas seguindo os cursos d'água, chamadas "linhas coloniais". Suas dimensões variavam entre 100 e 200 metros de largura por 600 a 1000 metros de comprimento, raramente ultrapassando $25 / 30$ hectares. O formato alongado, tecnicamente, dava acesso à via de comunicação e ao curso d'água para todos; e, sendo a topografia acidentada, supostamente garantia uma área de várzea para cada proprietário - fato possível nos traçados que acompanhavam os rios principais, mas não os ribeirões. A expedição dos títu- 
los provisórios exigia a ocupação efetiva do lote, com construção de moradia permanente (o colono devia residir na sua propriedade rural e não em áreas demarcadas com "lotes urbanos"). Como resultado, não houve formação de aldeias camponesas de tipo europeu, prevalecendo o modelo de povoamento disperso, definido por Waibel (1958) e Roche (1969), em que a unidade social comunitária era formada pelos ocupantes de uma linha.

O modelo de demarcação das terras também incluía lotes urbanos, bem menores, destinados a prestadores de serviços, comerciantes, administração, igrejas etc. - localizados junto ao rio em área reservada à futura vila. Esse tipo de núcleo deu origem à maioria das cidades que hoje são sedes municipais, e que os alemães denominavam Stadtplatz. Assim, a ocupação das terras iniciou-se a partir de um local demarcado com "Iotes urbanos", as linhas coloniais seguindo primeiro o rio principal e se ramificando, depois, pelos afluentes, em um afastamento progressivo de ocupação de terras cada vez menos apropriadas à lavoura.

Os imigrantes recebiam seus lotes por compra, a prazo, assinalada em título provisório, contraindo a chamada "dívida colonial" 5 . O título definitivo de propriedade só era expedido após a quitação da dívida, e a inadimplência demorada, ou mesmo o abandono do lote pelo concessionário, ocasionava a retomada da terra pela administração, para posterior venda em hasta pública (cf. Silva 1972; Seyferth 1996a). O planejamento cuidadoso e burocrático, imaginado como modelo perfeito de ocupação, na verdade, mascara a instabilidade do sistema que teve como resultado uma grande mobilidade dos colonos. $\mathrm{N}$ a realidade, as terras recebidas nem sempre eram adequadas à produção agrícola, os centros consumidores estavam longe, forçando os colonos a vender seus excedentes para comerciantes locais, trazendo problemas para a quitação da dívida colonial. Pagar a terra recebida em um prazo de cinco anos era quase impossível diante das condições adversas que geraram a mobilidade, isto é, a constante troca de um lote por outro (na mesma região colonial ou al hures), nem sempre dentro dos procedimentos legais, tornou-se prática comum. A ocupação de lotes - abandonados por seus concessionários ou não - sem conhecimento da autoridade colonial configurava "invasão", passível de expulsão ou, mais raramente, resolvida por arremate da terra em hasta pública (cf. Seyferth 1996a).

Nessas condições, a expedição dos títulos de propriedade podia demorar mais de duas décadas. A situação precária da ocupação, traduzida em crônica falta de recursos para agilizar os assentamentos em um contexto de fluxo imigratório relativamente constante até a segunda década 
do século XX, ocasionou protestos e conflitos com as administrações coloniais, sobretudo no início do povoamento (cf. Seyferth 1988; 1996a).

O modelo idealizado de colonização, configurado na legislação, nas plantas cadastrais e em uma visão de progresso reificada por uma parte da literatura específica, está distante da realidade enfrentada pela maioria dos imigrantes ao longo do processo colonizador da região. $M$ as, apesar dos problemas, a constância do fluxo imigratório e as demandas por terras das gerações subseqüentes de colonos impulsionaram a formação de um campesinato cuja base fundiária traduz-se na pequena propriedade familiar policultora. A identidade social de colono foi construída a partir de um ethos camponês, independentemente da procedência nacional dos imigrantes.

Essa referência identitária sugere um fluxo imigratório heterogêneo. O Vale do Itajaí aparece sempre como região de colonização "alemã", mas a exclusividade dessa etnia restringiu-se às duas primeiras décadas de ocupação. Os documentos coloniais registram a chegada de italianos, russos, húngaros, austríacos, irlandeses, franceses - uma heterogeneidade em parte provocada pelas dificuldades de aliciar imigrantes alemães (comentada nos escritos de Hermann Blumenau, por exemplo), mas também relacionada às preocupações das autoridades brasileiras com possíveis enquistamentos étnicos, o que recomendava "colônias mistas". Tal composição, aparentemente, quebra a homogeneidade germânica do Vale, mas não sua definição como "região de colonização alemã", fundamental na construção de uma identidade teuto-brasileira. De fato, só os italianos chegaram em número significativo; irlandeses e franceses retiraram-se após o fracasso econômico da colônia Príncipe D. Pedro (fundada e extinta na década de 1860 na margem esquerda do rio Itajaí-mirim); e os imigrantes originários da Rússia, Hungria e outros países do Leste Europeu, em parte, eram membros de minorias teutas ${ }^{6}$. Ao passarem à condição de sedes municipais, na década de 1880 , as vilas de Blumenau e Brusque apresentavam-se como "alemãs", nos termos da identificação étnica e cultural ali produzida.

\section{Diferenciação interna: a proeminência dos "vendeiros"}

A criação dos dois municípios, ato de emancipação das colônias Blumenau e Itajaí (Brusque), tem relação direta com o tema da ascensão social, em uma região onde a população nacional, isto é, os brasileiros, estava ausente. $\mathrm{Na}$ situação colonial os imigrantes estavam sujeitos a uma legis- 
lação específica e ao controle exercido pelas diretorias das colônias (sob supervisão do governo provincial e do M inistério da A gricultura), sem direitos de cidadania, (des)qualificados simplesmente como "colonos estrangeiros" - as naturalizações foram facilitadas somente após a primeira Constituição republicana. Por outro lado, a diferenciação interna produzida pelo sistema era pequena no meio rural e um pouco mais evidente nas duas vilas e suas proximidades, onde estavam estabelecidos os comerciantes e artesãos, e onde surgiram as primeiras indústrias, ainda na década de 1880.

As duas situações - a que configurava a existência de minoria nacional (embora negada oficialmente) e uma estratificação mais nítida em termos de classes sociais - surgiram, de forma mais contundente, no momento histórico da emancipação municipal, que aproximou a elite teuto-brasileira da realidade nacional.

O modelo de colonização produziu uma sociedade rural de pequenos proprietários - o lote (ou colônia, como até hoje é denominado) funcionando como unidade básica de um sistema de exploração agrícola camponês, caracterizado pela policultura e trabalho familiar, e pela utilização de técnicas agrícolas consideradas "primitivas" (cf. Waibel 1958). Os que traçaram os rumos da política de colonização esperavam, como resultado, uma agricultura moderna, de tipo capitalista, rentável - a partir da rotinização da concessão de 25 hectares na segunda metade do século XIX, especialmente nas colônias oficiais, caso de Brusque e Blumenau. Entretanto, nos primeiros anos de assentamento os colonos estabeleceram uma agricultura de subsistência, empregando a técnica da coivara (derrubadaqueimada e plantio manual com uso de enxada), sendo a produção destinada, em primeiro lugar, ao consumo da família, o excedente trocado nas casas comerciais locais (as "vendas"). M ais tarde, a introdução do plantio de fumo e a criação de suínos e gado leiteiro, bem como as possibilidades de beneficiamento de milho e mandioca em engenhos e atafonas, ampliaram as possibilidades da produção comercial. Houve, portanto, al gum incremento da atividade agrícola, com emprego da rotação de terras e cultivos, visando à conservação do solo. $\mathrm{O}$ discurso dos colonos sobre subsistência e policultura (val ores camponeses incompatíveis com a atividade econômica que privilegia o mercado) e o emprego da coivara, descrito na literatura, fizeram com que alguns autores consagrados assinalassem um processo de "caboclização" dos imigrantes e uma "instabilidade crônica" derivada da lavoura extensiva - caso de Willems (1940) e Waibel (1958), que usam essa imagem como forma de explicitar o que supõem seja uma conduta econômica pouco racional, pré-capitalista, con- 
siderada causa primordial da mobilidade geográfica (o deslocamento de uma área colonial para outra sempre em busca de terras virgens).

De fato, o lote de 25 hectares, assim como a continuidade dos assentamentos de novos imigrantes durante mais de cinqüenta anos, têm limitações, agravadas pelo esgotamento das terras em prazo curto. Pode servir às necessidades de uma família camponesa, mas torna-se impraticável para reproduzir socialmente a segunda geração, cujo destino mais óbvio seriam as novas áreas coloniais abertas dentro e fora do Vale do Itajaí. Richter (1986), por exemplo, assinala que mais de $50 \%$ dos interessados em adquirir lotes na colônia Hansa/Hammonia (Ibirama), no alto Vale do Itajaí, fundada em 1899, eram teuto-brasileiros provenientes de colônias mais antigas. Isso mostra a intensidade da migração interna, motivada pela pressão demográfica e pelo esgotamento dos solos, e também pela insuficiência reprodutiva dos 25 hectares, louvados na legislação, mas sem conter a minimale Ackernahrung - a quantidade mínima de terras necessária a uma família, tendo em vista não só a quantidade mas também a qualidade do solo. Segundo Waibel (1958), dadas as condições das terras destinadas à colonização, essa quantidade teria que oscilar entre 55 e 105 hectares; com apenas 25 hectares a rotação de terras é muito rápida, tendo como resultado uma produtividade cada vez menor.

Levando em conta a minimale Ackernahrung, que não é apenas um conceito técnico, mas supõe um "padrão econômico e social decente" na concepção alemã (Waibel 1958:240), e as altas taxas de natalidade registradas entre os colonos (cf. Willems 1946; Richter 1986), o assentamento de todos os herdeiros legais não era exeqüível. As regras costumeiras de herança da terra variavam conforme a tradição de origem dos imigrantes - podiam privilegiar os herdeiros masculinos, um herdeiro único (primogênito ou ultimogênito), ou simplesmente incluir todos os filhos na partilha. De qualquer modo, era quase impossível evitar a divisão das propriedades originais, a não ser nos casos em que a tradição camponesa da herança indivisa foi preservada. A recomposição do lote (mesmo em parcelas descontínuas), por sua vez, também dependia da disponibilidade financeira para comprar terras, nem sempre possível para aqueles que não conseguiram quitar a dívida colonial no prazo legal de cinco anos.

Tudo isso aponta para dois fatores cruciais no que concerne à ascensão social: a diferenciação interna no segmento dos $\operatorname{colonos}^{7}$ e a existência de uma população camponesa excedente, antes mesmo de se completar a colonização do Vale do Itajaí. A posse de terras mais férteis, a maior proximidade da Stadtplatz, a possibilidade de trabalho temporário na abertura de estradas e na demarcação de lotes (que proporcionava 
ganho monetário ou mesmo o abatimento da dívida colonial), o conhecimento de algum ofício de artesão, são fatores de diferenciação importantes nas primeiras décadas de ocupação do território.

O primeiro ponto a considerar, portanto, é que esse segmento rural produzido pela colonização nada tem de homogêneo; mas, embora diferenciado, as distâncias sociais eram pequenas, e o principal efeito do regime de pequena propriedade familiar, pode-se dizer, foi a constituição de uma classe média rural relativamente estável - uma estabilidade garantida também pela migração. $O$ segundo ponto diz respeito ao destino dos migrantes: repetir o ciclo pioneiro dos pais em outra colônia, próxima ou distante, ou dirigir-se às cidades em formação para obter emprego nas indústrias que surgiram no início do período republicano. Naquele momento, qualquer outro investimento de reprodução social - como a ascensão pela via educacional - era extremamente difícil e restrito aos que desistiram de permanecer na condição de colonos e se deslocaram para Itajaí ou Desterro (Florianópolis).

No seu estudo sobre a colonização alemã no Rio Grande do Sul, Roche (1969) mostra que os comerciantes constituíram a única classe que enriqueceu nas colônias, e as indústrias puderam ser implantadas por meio do capital acumulado por eles (denominados "vendeiros") em transações que envolviam a compra dos excedentes produzidos pelos colonos. A situação não divergiu muito no Vale do Itajaí. Os principais "vendeiros" eram alemães estabelecidos nos núcleos urbanos - Blumenau e Brusque alcançaram a condição de vila, respectivamente, em 1880 e 1882, atribuída no ato legislativo que elevou as duas colônias a municípios. Ali estavam concentradas as atividades administrativas, as associações recreativas e beneficentes, algumas escolas, as igrejas (evangélica-luterana e católica), muitas das atividades artesanais e o comércio. Por outro lado, as duas vilas tornaram-se atrativas para aquela parcela de imigrantes assentados em lotes coloniais, mas que não vinham de uma tradição agrícola. $\mathrm{N}$ a fase inicial de colonização, um certo número de pequenas empresas industriais, de beneficiamento de produtos agrícolas e atividades artesanais, surgiu nas vilas ou em sua periferia - alambiques, moinhos, cervejarias, fábricas de charutos, cortumes, marcenarias, ferrarias etc. - , quase sempre familiares, mas que também possuíam assalariados (cf. Mamigonian 1965; Seyferth 1974). Os próprios comerciantes envolveram-se nesse tipo de produção, além de explorar serrarias. O que se pretende mostrar com esta breve menção à diversificação das atividades econômicas no contexto da Stadtplatz é simples: de modo diverso da área rural, ali se produziu uma estratificação social mais evidente, destacan- 
do-se uma pequena elite formada, principalmente, por comerciantes, alguns dos quais estabeleceram as primeiras indústrias têxteis da região no final do século XIX.

A relação econômica mais importante das primeiras décadas foi, certamente, a que se estabeleceu entre comerciantes e as unidades produtivas chamadas "colônias". A palavra colônia tem, na realidade, um duplo significado: designa a área rural (com suas "linhas"), em sua totalidade, e sua fração mínima, o lote ou pequena propriedade familiar do colono - unidade de produção policultora, cujos excedentes, por meio das trocas realizadas nas "vendas", passavam às mãos dos comerciantes. Estes, no início, operacionalizavam as transações sem usar dinheiro, em um sistema de trocas no qual os colonos deixavam seus produtos e levavam mercadorias não produzidas na colônia - como ferramentas, equipamentos, sal, querosene, tecidos etc. Muitos comerciantes possuíam serrarias e engenhos destinados à fabricação de fubá, açúcar e farinha de mandioca; a matéria-prima, nos dois casos, também era fornecida pelos colonos. Esse tipo de comércio cresceu com a expansão da área colonizada, apesar do início bastante modesto. E cresceu porque os "vendeiros" tinham o controle dos mecanismos que regulavam as transações: arbitravam o valor das mercadorias trocadas, instituíram um sistema de conta corrente (assinalando o que era deixado pelos colonos e o que estes levavam em troca, em um processo quase infindável de endividamento dos que produziam menos excedentes) e tinham o controle do transporte para Itajaí através do rio. Resumindo, os excedentes econômicos advindos da produção agrícola camponesa acumulou-se nas mãos dos "vendeiros".

As casas comerciais mais importantes estavam situadas nas vilas; nos entroncamentos das estradas e picadas rurais também surgiram algumas "vendas", que podiam ser filiais ou, às vezes, propriedade de um colono. De qualquer modo, a documentação disponível sobre a colonização mostra o domínio econômico exercido pelos comerciantes, evidenciado em abaixo-assinados ou cartas reclamando das disparidades dos preços, que deixavam os colonos sempre em dívida com os "vendeiros", ou solicitando a abertura de estradas para Itajaí, em uma crítica ao monopólio dos barcos vinculados às "vendas" (cf. Seyferth 1974).

Em Blumenau ou em Brusque, os comerciantes eram imigrantes alemães, alguns de origem social modesta e com pouco capital escolar. No final do século XIX, dentre os comerciantes de Blumenau podem ser identificados um camponês, um alfaiate, um marinheiro, um canoeiro (cf. Mamigonian 1965:397-398); em Brusque, dois dos mais importantes “vendeiros" eram camponeses que deixaram seus lotes para explorar madei- 
ra, e os demais vinham da classe média, com curso secundário completo realizado na Alemanha.

Os comerciantes, então, formavam a elite econômica das duas sedes municipais criadas pela emancipação política das colônias Blumenau e Brusque, no início da década de 1880 . Acumularam capital suficiente para investir na atividade industrial, embora nem todas as indústrias tenham surgido diretamente ligadas ao sistema colônia-venda. A lguns exemplos podem servir como ilustração do início do processo de industrialização nas duas localidades.

A primeira indústria têxtil de Blumenau - portanto, sem vinculação com matérias-primas produzidas pelos colonos - surgiu em 1880: uma pequena malharia de propriedade de Hermann Hering, um imigrante que chegou a Blumenau em 1878. Antes de instalar a tecelagem foi escriturário de comerciantes, instal ou uma manufatura de charutos e abriu uma pequena casa de comércio, segundo Mamigonian (1965), um "verdadeiro botequim". A pós a instalação da malharia, iniciada com um tear, convenceu o irmão e o restante da família (sua mulher e filhos) a emigrar para Blumenau (cf. Hering 1987). Ambas as atividades (comércio e tecelagem) já eram tradição familiar na Saxônia, onde suas pequenas empresas estavam em crise, principal razão da transferência para o Brasil.

J ohann Karsten, um camponês do Schleswig-Holstein, recebeu um lote colonial em Blumenau mas, além da lavoura, também explorou um moinho e uma serraria de pequeno porte; Heinrich Hadlich possuía uma pequena casa comercial na vila; e Gustav Roeder, um mestre-tecelão, não quis se estabelecer como colono. Os três fundaram a segunda indústria têxtil de Blumenau em 1882, com seis teares. Roeder deixou a sociedade em 1885 para fundar outra fábrica de tecidos, localizada junto ao ribeirão Garcia (recebendo, por isso, a denominação de Empresa Industrial Garcia, que mais tarde passaria para o controle de dois importantes comerciantes locais, H. Probst e Luis Sachtleben). No mesmo local já havia uma pequena tecelagem, da qual se tem poucas informações, pertencente a um alemão de nome Grewsmuehl (cf. Hering 1987).

Ainda nessa década surge a fundição de Karl Auerbach, embrião de uma das primeiras empresas a produzir aço no Brasil.

Em Brusque, as duas principais indústrias são criadas ainda no sécuIo XIX: uma fábrica de tecidos, em 1892 - iniciativa do "vendeiro" Carlos Renaux, cuja trajetória será especificada mais adiante, associado a Augusto Klappoth e Paul Hoepcke, ambos comerciantes, o último estabelecido na capital, Florianópolis - , cujo sucesso dependeu da contratação de um grupo de imigrantes tecelões, de origem germânica, oriundos 
da região de Lodz, Polônia; e uma fábrica de bordados, instalada em 1898 por Eduardo von Buettner, um comerciante com passagem por pelo menos três outras colônias alemãs de Santa Catarina (J oinville, São Pedro de A lcântara e Blumenau), trabalhando para outros vendeiros.

Outros comerciantes notáveis de Brusque (C. Krieger, M. Heil e J . Bauer) permaneceram na atividade tradicionalmente ligada à produção colonial, inclusive o comércio de madeira. Os três tinham origem camponesa.

O surgimento dessas indústrias é apenas uma faceta da diversificação das atividades econômicas nas duas vilas, antes do início do século $X X$; elas se desenvolveram de forma mais acelerada a partir da eletrificação na década de 10 que, junto com os incentivos à indústria nacional concedidos após a proclamação da República, permitiram o surgimento de outras empresas na região.

As indústrias foram instaladas na periferia das vilas e recrutaram a mão-de-obra necessária entre os colonos. A rigor, a denominação de Stadtplatz apontava, principalmente, para certas funções urbanas mais do que para a condição de cidade. O município de Blumenau tinha uma população de 16.380 habitantes em 1882, e menos de mil viviam na área considerada urbana (Silva 1972:136); o município de Brusque tinha 14.900 habitantes em 1900 - na vila moravam menos de mil. Nos dois casos, o desenvolvimerto urbano e a industrialização foram simultâneos, em uma fase em que prosseguiam os assentamentos coloniais na região.

Em ambas formou-se uma camada média, incluindo pequenos comerciantes, artesãos, técnicos especializados, prestadores de serviços, professores, servidores públicos etc.; uma classe operária, composta por egressos do meio rural, mas também por imigrantes que preferiram uma ocupação urbana à alternativa do lote colonial em local distante; um segmento de worker-peasants (operários que continuaram ligados à atividade rural em tempo parcial); e uma elite formada pelos principais comerciantes/industriais, com interesses políticos postos em evidência a partir da criação dos dois municípios. O número de brasileiros era bastante reduzido no período inicial de industrialização, pois foram poucos os que participaram dos projetos coloniais. No entanto, havia um pequeno grupo de funcionários públicos oriundos de famílias tradicionais de Santa Catarina ou de outras regiões do país, de "origem lusa" conforme os padrões locais de classificação étnica, concorrentes diretos da elite teutobrasileira nas disputas políticas locais8.

Assim, o desenvolvimento do comércio e da indústria desde a década de 1880, bem como a emancipação das colônias, colocam em evidên- 
cia uma questão importante: imigrantes e descendentes estavam localizados em uma região onde a sociedade nacional inexistia, mas a nova situação político-econômica exigia a assimilação como condição da cidadania. Isso aponta para a questão da etnicidade e para o fato simples da apresentação de ambas as vilas como "comunidades germânicas".

\section{0 discurso étnico teuto-brasileiro}

A elaboração de um discurso étnico que tem por referência a história da colonização, idealizada pela idéia de construção de uma nova pátria (Heimat) no Brasil, coincide com a criação dos municípios e a expansão das atividades industriais nas duas vilas. Essa coincidência não é mero acaso. $\mathrm{Na}$ situação colonial, todos compartilhavam a identidade de colonos estrangeiros - a maioria sequer tinha obtido a naturalização, um processo difícil durante o Império, principalmente para os não católicos (contingente expressivo na região). O problema da naturalização foi resolvido no início da República mas, em termos da cidadania, teve pouco resultado porque o conceito-chave para definição do cidadão, nesse caso, era assimilação. Nem a naturalização, nem o jus soli asseguravam a cidadania plena para os não assimilados (categoria que incluía todos os falantes da língua alemã). A necessidade de integração na economia nacional e as aspirações políticas das elites locais, de certa forma, forçaram al gumas estratégias assimilacionistas, como a utilização do português como segunda língua, a obtenção de patentes de coronel da Guarda Nacional, a convivência com as novas autoridades luso-brasileiras presentes na sociedade local, ou mesmo o estabelecimento de relações com pessoas ou grupos fora da área colonial germânica. No entanto, esse processo de ruptura das fronteiras étnicas é apenas aparente, e o que emerge é uma concepção identitária teutobrasileira na qual a Deutschtum (ou germanidade) tem valor fundamental.

A imagem passada pela ideologia étnica não é apenas figura de retórica. Nas primeiras décadas da República o idioma falado nas áreas rurais e urbanas do Vale do Itajaí era o alemão. Em algumas localidades, como Guabiruba, é comum, até hoje, o uso da língua materna (um dialeto germânico) por descendentes de imigrantes badenses e italianos do norte (embora nas "colônias italianas" com pouca presença alemã predominasse o idioma italiano). No período anterior à Segunda Guerra M undial, o português só era a segunda língua de uma parcela pequena da população. As características "germânicas" são ressaltadas por vários autores brasileiros com passagem pela região, ou que lá viveram: arquitetura, 
cemitérios, traçado urbano, organização das atividades rurais (com a policultura) - aí incluída a distribuição espacial da casa, estábulo, roças, horta e pomar dentro do lote colonial -, diversificação econômica observada no espaço urbano, com grande número de pequenas empresas artesanais e familiares, hábitos de lazer etc., constituem motivo de estranhamento e preocupação com o "enquistamento" étnico da população (cf. Duarte 1917; Nogueira 1947; D'A maral 1950). Manuel Duarte, por exemplo, em seu relato de viagem pelas colônias de Santa Catarina, definiu Blumenau como "corpo estranho" dentro da "comunidade nacional", impermeável à assimilação. Max D'A maral, por sua vez, parece impressionado com a disposição dos germânicos para o trabalho (incorporando, assim, um dos elementos definidores da germanidade, a suposta capacidade inata para o trabalho, da qual a colonização bem-sucedida é um dos efeitos) e com o modelo de Wohnkultur (a casa como traço característico e diferenciador do modo de vida entre alemães e brasileiros - 0 "hábito de morar bem"). Rui Nogueira reclama da arquitetura, das lápides tumulares em caracteres góticos, do excesso de bicicletas nas ruas, da multiplicidade de bailes em todos os cantos da colônia. Enfim, a conservação de usos e costumes do país de origem e o modelo de colonização com pequena propriedade familiar produziram diferenças sociais consideráveis em relação à sociedade nacional, observadas com certa preocupação por muitos brasileiros. M as, se os hábitos cotidianos, o modo de vida e o ethos do trabalho suscitaram expressões de estranhamento por parte de muitos brasileiros, as instituições comunitárias definidas como germânicas eram condenadas, junto com o uso da língua alemã, como ameaça maior a qualquer projeto assimilacionista, por seu comprometimento ideológico com o nacionalismo alemão.

Dentre essas instituições devem ser destacadas: as associações culturais e recreativas (Schützenverein, Gesangverein, Turnverein, respectivamente, sociedades de atiradores, de cantores e de ginástica); as associações de apoio aos colonos (caso da Kulturverein)'; a rede escolar particular alemã de ensino (ou "escolas alemãs"), ligada às igrejas (evangélica-Iuterana e católica) ou de manutenção comunitária; a imprensa em língua alemã (até 1939 circulavam pelo menos quatro jornais importantes editados no Vale do Itajaí - Der Urwaldsbote, Blumenauer Zeitung, Brusquer Zeitung e Rundschau, respectivamente, O Correio da Selva, J ornal de Blumenau, J ornal de Brusque e Panorama), além das publicações oriundas de outras "colônias alemãs". Em Blumenau também foi formada uma associação com finalidades políticas - dar apoio a candidatos de origem germânica e obter cadastramento eleitoral para os alfabetiza- 
dos em alemão -, a Volksverein, em atividade até 1917 (cf. Seyferth 1994a). Essas instituições apareciam como "guardiãs do espírito (Geist) germânico", da germanidade (Deutschtum), preservadoras das tradições e da língua, tomadas como critérios primordiais de definição de uma etnicidade teuto-brasileira por seu comprometimento com as qualidades intrínsecas do grupo étnico. Os comerciantes e industriais tinham papel destacado nas associações, e alguns deles controlavam os jornais, principais veículos para textos que reverenciavam o pertencimento étnico e reivindicavam uma identidade teuto-brasileira.

A palavra Deutschtum tem dois sentidos que convergem para compor a etnicidade teuto-brasileira: expressa o sentimento de superioridade do "trabalho alemão" - e, neste caso, remete ao progresso trazido pelos pioneiros à "selva" brasileira - e define o pertencimento à etnia alemã, estabelecendo seus critérios - língua, raça, usos, costumes, instituições, cultura alemães.

O primeiro sentido tem relação com o processo histórico de colonização associado à idéia de Heimat: o trabalho "pioneiro" de construção de uma sociedade nova e progressista, literalmente a edificação de uma nova pátria no Brasil ou, mais restritamente, no Vale do Itajaí. Daí o emprego da palavra Heimat (pátria), derivada de H eim (lar) - no seu sentido mais particularista a pátria deve coincidir com o lugar onde o indivíduo tem o seu lar. Ou pode ser, simplesmente, a comunidade étnica que, para ser alemã, deve expressar Deutschtum - e aí está o segundo sentido, englobando a idéia de raça, língua, cultura e espírito. Desse modo, define-se o pertencimento à etnia/nação alemã pelo jus sanguinis, instituindo uma germanidade materializada por intermédio da "colônia alemã".

Ao mesmo tempo, cria-se uma categoria de identificação com hífen (teuto-brasileiro), para traduzir uma germanidade brasileira (Deutschbrasilianertum) - modo de afirmação da cidadania mediante a integração econômica, política e patriótica, ancorada no pressuposto de que não existe, propriamente, uma nação brasileira. A definição da categoria teutobrasileiro (Deutschbrasilianer) combina jus sanguinis e jus soli: origem alemã e cidadania brasileira, pertencimento à nação alemã e ao Estado brasileiro visualizado como multirracial ou multiétnico. Na esfera comunitária - o Vale do Itajaí — ser teuto-brasileiro é agir, viver, comportar-se como "alemão", enquanto na sociedade mais ampla pode-se pensar apenas como brasileiro, pois ali não existe a Volksgemeinschaft (comunidade nacional).

A concepção de etnicidade foi amplamente reificada na imprensa, em uma literatura produzida por teuto-brasileiros, até em textos comemorativos das associações culturais e mesmo das escolas e igrejas. Alguns 
jornais, como o Der Urwaldsbote, usaram uma linguagem racista para afirmar a superioridade do trabalho alemão e defender a endogamia e, algumas vezes, procuraram legitimar a existência do grupo étnico pela assertiva de que o Brasil não era uma nação porque seus cidadãos não formavam uma raça ou povo homogêneo, reivindicando para cada grupo imigrado o direito à singularidade. Vários artigos do Der Urwaldsbote publicados no início do século ironizam os ideais brasileiros de branqueamento da raça, recusando a miscigenação com o Volkerbrei (mingau de povos), segundo seus termos, composto de inferiores (cf. Seyferth 1982). Por outro lado, eram freqüentes as reivindicações que procuravam dar legalidade ao grupo étnico, como: oficialização da língua alemã, garantia de funcionamento para as escolas étnicas, cadastramento eleitoral dos alfabetizados que desconhecessem o idioma português etc.

$M$ ais do que as diferenças concretas, caracterizáveis como étnicas, o discurso sobre Deutschtum e Deutschbrasilianertum, e a ênfase, principalmente da elite local, na identidade teuto-brasileira, deram margem a conflitos, principalmente para aqueles cuja trajetória de ascensão social ultrapassou os limites da comunidade local, e pelo fato de a etnicidade ser considerada pelos brasileiros como obstáculo à assimilação e risco para a unidade nacional. $\mathrm{Na}$ verdade, a assimilação cultural e o investimento escolar obtido fora da comunidade étnica foram canais privilegiados de ascensão social, especialmente para os que estavam situados nas camadas médias emergentes do sistema de colonização. Afinal, no início do século, nas duas vilas só havia o equivalente ao ensino de primeiro grau - ir adiante na escolarização exigia a transferência para Porto Alegre, São Paulo ou Rio de J aneiro.

\section{Duas trajetórias exemplares: o sucesso na política}

A trajetória mais espetacular envolvendo esses dois caminhos - a assimilação e a escolarização - é a de Lauro Severiano M üller (1863-1926), definido por Oberacker J r. (1968: 413) como "o mais destacado dos estadistas brasileiros, filho de alemães". A família Müller fazia parte do primeiro contingente de imigrantes alemães que se fixou na colônia de São Pedro de Alcântara em 1829. O avô, J ohann, de origem camponesa, recebeu um lote colonial, explorado por ele e seus filhos menores; portanto, Lauro M üller era filho de um colono. Mas seu pai, Peter, abandonou a atividade agrícola para trabalhar como embarcadiço nos barcos que faziam a linha Desterro (Florianópolis)-Itajaí. A mãe, Anna Michells, era filha de 
outro colono da primeira leva de imigrantes, que havia se retirado para Itajaí, onde abriu uma casa comercial. A pós seu casamento, Peter Müller mudou-se para Itajaí, onde também ingressou, com o irmão, na atividade comercial - escolha lógica para estabelecer uma casa comercial, pois era o lugar para onde convergia a maior parte da produção agrícola e manufatureira do Vale do Itajaí. Lauro, o quinto filho, nasceu em 8/11/1863, em Itajaí.

Sua primeira inserção escolar é significativa: foi educado no idioma alemão, em uma escola primária particular teuto-brasileira, em Blumenau, onde residia seu tio, Bernardo Haendschen, casado com uma irmã de seu pai, uma vez que não havia escola alemã em sua cidade natal. O tio também era pequeno comerciante, uma estratégia familiar para sair da condição de colono e integrar a classe média urbana em formação nas áreas coloniais e sua periferia. Lauro Müller freqüentou, ainda, por algum tempo, uma escola pública brasileira, forma de ser teuto-brasileiro assimilado em condições de ingressar em uma escola secundária fora do seu estado de origem. A os 16 anos foi enviado ao Rio de J aneiro para aprendizado em uma casa comercial, de onde saiu para concluir os estudos de 2o grau em Niterói. A os 19 anos ingressou na Escola Militar do Rio de J aneiro, onde obteve o grau de engenheiro-militar e se tornou alferes em 1887. Em 1889 era tenente-engenheiro do Exército nacional, tendo passado pela doutrinação republicana positivista de Benjamim Constant. Servia como ajudante-de-ordens do marechal Deodoro da Fonseca por ocasião da proclamação da República - um acaso fundamental no processo de ascensão social pela via política, pois veio a ser nomeado governador provisório de Santa Catarina aos 26 anos de idade. A partir daí sua carreira política, vinculada ao Vale do Itajaí, teve andamento rápido: foi eleito senador Constituinte em 1890, voltou a ocupar o cargo de governador em 1891 (cargo para o qual seria novamente eleito em 1902 e 1918); além disso, venceu diversas eleições para deputado federal e senador, e ocupou o cargo de ministro de Estado por duas vezes (M inistério da Viação, no governo de Francisco de Paula Rodrigues Alves, 1902-1906; e M inistério do Exterior, em substituição ao Barão do Rio Branco, de 1912 a 1917, nos governos Hermes da Fonseca e Venceslau Braz).

O outro fato político que deu impulso à carreira de Lauro Müller diz respeito à sua posição legalista (como político catarinense apoiou o marechal Floriano Peixoto), durante a revolução federalista em 1893. O movimento revolucionário contra o governo de Floriano Peixoto iniciou-se no Rio Grande do Sul, com a formação do Partido Federalista, obtendo a adesão de um grupo significativo de políticos de Santa Catarina, inclusive de 
Blumenau. Lauro M üller teve de renunciar ao governo do estado por sua posição em favor dos florianistas e, como capitão do Exército, juntou-se às tropas que combatiam as forças rebel des no Paraná, participando do combate decisivo, o cerco da cidade de Lapa que culminou com a derrota dos federalistas.

A revolução federalista criou divisões políticas quase irreconciliáveis em Santa Catarina, especialmente em Blumenau, e terminou em um grande ajuste de contas patrocinado pelo coronel A ntonio M oreira Cezar, nomeado governador por Floriano Peixoto em abril de 1894. A pós combate naval em Desterro, e assumir o controle da situação, fez quase duas centenas de presos políticos, civis e militares, que seriam mortos na fortaleza de Santa Cruz (Cabral 1970:274). Terminada a revolução, Lauro M üller foi eleito deputado federal e, segundo a historiografia local, não só se tornou o "chefe inconteste da política republicana no Estado" como foi "o pacificador da política de Santa Catarina quando, em 1901, promoveu a unificação dos partidos Republicano e Federal ista" (Cabral 1970: 281 e 284), o que representou a unificação de duas das facções políticas blumenauenses, mas deixou de fora o grupo mais fortemente germanista.

Visualizando a trajetória política de Müller, emerge com clareza sua integração às práticas políticas brasileiras e sua condição de assimilado exemplar, descendente "ideal" de imigrantes. Essa classificação não é tão simples no discurso teuto-brasileiro, principalmente no dos seus adversários políticos em Blumenau, que o apresentam, às vezes, de forma negativa, como uma espécie de renegado do grupo étnico, especialmente o jornal Der Urwaldsbote. Na realidade, a posição teuto-brasileira sobre a carreira de M üller é variada e, às vezes, ambígua, mas de modo algum incoerente com os princípios da germanidade. Por um lado, o fato de ter sido bem-sucedida é apresentada como decorrência da germanidade, isto é, o sucesso político também é Deutschtum, expressão do “trabalho alemão". Por outro, serve como exemplo da dedicação teuto-brasileira ao país, ou à nova pátria e, nesse caso, M üller é o cidadão teuto-brasileiro exemplar. Já para os adversários políticos empenhados no cadastramento eleitoral da população de origem alemã, é excessivamente (luso) brasileiro e comprometido com as práticas de exclusão política dos colonos (cf. Seyferth 1994a; 1996b). Esse aspecto deve ser ressaltado porque remete ao sistema classificatório étnico usado no Vale do Itajaí, onde luso-brasileiro (branco, descendente do colonizador português ou, eventualmente, de açorianos) constitui a principal categoria construída por oposição ou contraste à identidade teuto-brasileira (ver nota 8). 
Do ponto de vista teuto-brasileiro, portanto, a trajetória de Müller pode ser um exemplo das virtudes étnicas, da capacidade germânica refletida no comportamento de um cidadão fiel ao seu país, mas que se manteve "alemão" até por decisão familiar (tendo em vista sua educação em uma "escola alemã") - conforme consta da biografia publicada no volume comemorativo do centenário da imigração alemã em Santa Catarina (cf. Entres 1929) -, apesar de eventuais acusações de lusofilia saídas, principalmente, de contextos mais radical mente germanófilos ${ }^{10}$. A idéia de Deutschtum é suficientemente elástica para, transformada em Deutschbrasilianertum pelas elites locais, englobar a assimilação pela cidadania, justificando-a como meio de ascender no contexto da sociedade brasileira.

No entanto, Lauro M üller volta a encarnar a condição de membro de minoria nacional no episódio da sua saída do M inistério do Exterior, pouco antes da declaração do estado de guerra com a A lemanha em 1917. Nesse contexto, o assimilado exemplar volta a ser alemão, na forma como sua condição étnica aparece no volume comemorativo acima mencionado. Ali, o biógrafo constata "o fato de que o dr. Lauro M üller tinha legítimo orgulho do seu sangue alemão", e a passagem "pelos cargos políticos da nova pátria, inclusive pela Academia Militar, ocorreu sem que ele esquecesse sua origem alemã ou a língua e os costumes alemães" (Entres 1929:270). As publicações teuto-brasileiras, assim, afirmaram com vigor a identidade com hífen, com seu duplo significado de pertencimento (sangue alemão/patriota-cidadão brasileiro).

Enfim, no curso da Primeira Guerra Mundial, Lauro M üller foi acusado, principalmente pelos setores políticos favoráveis aos aliados, de germanofilia, de ter "mentalidade alemã", de evitar de todas as maneiras declarar guerra à Alemanha em razão dos interesses teuto-brasileiros. No período da guerra chegaram ao auge as especulações sobre o "perigo alemão" (a probabilidade de anexação dos estados do sul pela Alemanha, ou uma secessão política patrocinada pelo governo alemão), e a posição de neutralidade defendida por M üller e seu investimento nas relações com a Argentina e o Chile, foram interpretados como decorrente da sua provável germanofilia. Eventuais afirmações de germanidade, como a da história repetida em Luebke (1987:113) ajudaram a compor um perfil demasiadamente teuto-brasileiro para os princípios da brasilidade. Trata-se de episódio ocorrido em uma recepção em sua homenagem, quando uma criança teria perguntado o que ele era, esperando possivelmente uma resposta relacionada a cargo ou profissão, e M üller respondera: "eu sou um alemão" - ato falho de grande repercussão, sufi- 
ciente para destruir a reputação do assimilado que, no pedido de demissão do cargo de ministro se afirma "apenas um brasileiro" .

A trajetória de Lauro Müller e sua saída da vida pública mostram as dificuldades decorrentes da confirmação de uma condição étnica no âmbito do Estado nacional, no qual não há espaço para etnicidades, sempre visualizadas como ameaçadoras da unidade política e cultural.

Outro exemplo de trajetória ascendente, com ponto de partida na atividade comercial, é a de Carlos Renaux (1862-1945), fundador da principal indústria têxtil de Brusque. Era de uma família de classe média do Grão-Ducado de Baden, tinha escolaridade de segundo grau e treinamento como aprendiz no Banco Hipotecário de Loerrach, sua cidade natal. Emigrou para o Brasil em 1882, com carta de recomendação do banco mencionado e, no contexto de uma rede de ajuda mútua entre imigrantes (composta de pequenos e médios comerciantes), foi acolhido como caixeiro de uma "venda" em localidade próxima a Blumenau; em seguida, deslocou-se para a vila de Gaspar, onde Luiz Altemburg, seu novo empregador e um dos principais comerciantes de Blumenau, tinha uma filial. Em Gaspar, casou-se com a filha de Pedro Wagner, "pioneiro" reverenciado que participara da fundação da primeira colônia alemã de Santa Catarina e do primeiro assentamento ocorrido em Gaspar em 1835 - e caso raro de colono próspero apenas na atividade agrícola11. A pós o casamento, nova troca de emprego, dessa vez para assumir, em Brusque, o cargo de gerente da filial de Asseburg \& Willerding, atuante no comércio de exportação de produtos coloniais em Itajaí. Um ano depois, adquiriu a filial que estava gerenciando, sendo, para isso, fundamental o dote recebido por sua mulher. A passagem de empregado a proprietário, portanto, foi facilitada pelo bom casamento realizado, embora este fato seja minimizado por relatos que procuram enfatizar, em primeiro lugar, a capacidade empresarial verdadeiramente capitalista em um meio onde predominava a "troca em espécie". Essa simplificação pode ser vista no trabalho inédito de Buggenhagen (1941) e também no estudo sobre a industrialização catarinense realizado por Hering (1987). Em ambos os textos, os outros três grandes comerciantes de Brusque, no período inicial da industrialização do município - Krieger, Bauer e Buettner -, são apresentados como negociantes que não usavam dinheiro nas transações locais (certamente um exagero, tendo em vista a diversidade de atividades nos três casos, sendo que um deles se tornaria o segundo industrial mais importante da região). Renaux aparece como o empresário perfeito, moderno, que introduziu “princípios comerciais até então desconhecidos, ou melhor, não usados no local, ao 
substituir a troca em espécie de mercadorias por dinheiro" (Hering, 1987:75). Visão laudatória à parte, o fato é que, com dois sócios também "vendeiros" (ambos estabelecidos fora da área colonial, um deles na capital Desterro), inicia uma indústria têxtil em 1892, sem que sua casa comercial chegasse a se equiparar às outras três, apesar da "modernização capitalista" louvada por Buggenhagen e Hering.

O sucesso do empreendimento industrial, por outro lado, tem a ver com a presença de um grupo de tecelões oriundos da cidade de Lodz (Polônia), imigrado em fins da década de 1880, e que estava insatisfeito com a atividade agrícola, preferindo um emprego urbano (cf. Seyferth 1974; Hering 1987). O fato indica a diversificação das atividades econômicas na vila e a presença de imigrantes com diferentes formações profissionais encaminhados para a atividade agrícola - forma mais fácil de entrar em uma região de colonização em conformidade com a legislação. Renaux desenvolveu sua indústria têxtil (ampliada com a instalação de uma fiação em 1900), usando o capital acumulado na sua loja de Brusque, basicamente em transações com a produção colonial, fazendo empréstimos com um dos seus sócios (Paul Hoepcke, de Florianópolis), além de pequenas quantias obtidas junto a colonos remediados e de empréstimos realizados com uma firma de $\mathrm{H}$ amburgo (portanto, entraram também capitais alemães). As fábricas tiveram problemas financeiros até o final da Primeira Guerra M undial, mas a eletrificação, em 1913, deu um certo impulso à produção. Com a quitação do empréstimo feito na Alemanha, em 1917, a situação da empresa melhorou, e na década de 40 era uma das mais importantes indústrias do estado. Quando faleceu, em 1945, Renaux era o principal industrial e o cidadão mais notório de Brusque.

Do ponto de vista estritamente econômico, esta é uma das muitas histórias de sucesso que ilustram, em tom laudatório, a "contribuição alemã" para o desenvolvimento brasileiro, como podemos observar nas publicações comemorativas (cf. Entres 1929; Álbum do Centenário de Brusque 1960) que destacam as realizações dos imigrantes e seus descendentes, sempre evocando Deutschtum. Existe, entretanto, outra faceta da trajetória de Renaux: sua ligação com a vida política local. Em 1890, nomeado pelo governo estadual, integrou a Câmara M unicipal, juntamente com mais quatro imigrantes naturalizados, todos ligados a atividades comerciais. Entrou na política como partidário de Lauro M üller e Felipe Schmidt12. Foi eleito, em seguida, para compor a Assembléia Constituinte de Santa Catarina em 1891, e na revolução federalista estava entre os legalistas, participando, inclusive, das lutas contra os revoltosos na 
capital (cf. Álbum do Centenário de Brusque 1960:304). Exerceu, também, o cargo de superintendente municipal, eleito em 1904 e 1915. Não cumpriu o segundo mandato, passando o cargo para o vice eleito, seu filho Otto Renaux (que se casou com a filha de outro "vendeiro" importante) ${ }^{13}$. Depois de 1920 voltou à Europa onde foi cônsul do Brasil na Holanda e em Baden-Baden, seu estado natal. Estava, pois, no exterior a serviço da "nova pátria", voltando a Brusque na década de 30. A pesar do crescimento das indústrias que fundou, elas permaneceram na condição de empresa familiar (situação que só mudou na década de 70).

A trajetória de Renaux é representativa da dualidade implícita na categoria de identificação étnica: apresenta-se como brasileira nos dois aspectos vinculados à cidadania, político e econômico, ambos evidenciados nas representações sobre Deutschbrasilianertum como deveres para com a nova pátria. Da mesma forma, como teuto-brasileiro, serviu como representante diplomático na Europa e, em especial, na Alemanha. Mas, por outro lado, desenvolveu sua fábrica com técnicos trazidos da Alemanha antes e depois da Primeira Guerra M undial, inclusive um primo, Max Ludin, nascido na mesma cidade de Loerrach; e participou ativamente nas instituições comunitárias étnicas, inclusive como benemérito, nas festas e solenidades que louvavam a vinculação com a nação alemã, e nas homenagens de caráter germanista como, por exemplo, a recepção oferecida em Itajaí aos oficiais do navio de guerra alemão Panther, em 1905, envolvidos, posteriormente, em um episódio de ofensa à soberania brasileira que redundou em uma crise diplomática com o II Reich, com repercussão internacional (cf. Seyferth 1994b).

Finalmente, esse é um caso exemplar da eficiência acumulativa do sistema colônia-venda, vigente não só no Vale do Itajaí mas em outras regiões coloniais, no qual "com os lucros tirados da colônia os vendeiros conseguiram as somas necessárias para iniciar as indústrias" (Buggenhagen 1941:54). E corrobora a constatação de Roche (1969) sobre a simbiose dos comerciantes com os colonos, que produziu o único segmento realmente próspero no contexto do processo histórico de colonização. A rede de comércio, desde as áreas rurais, com suas "vendas" mais modestas, até as vilas e, depois, na capital (onde estavam localizadas as empresas mais importantes atuando na exportação/importação), era constituída por teuto-brasileiros, a maioria egressa do próprio meio colonial (caso da família de Lauro M üller e muitas outras) ou de camadas médias alemães (caso de Carlos Renaux e dos irmãos Hering). 


\section{Considerações finais}

A noção de Deutschbrasilianertum, enquanto definidora de uma etnicidade teuto-brasileira, inclui a possibilidade de uma integração político-econômica à sociedade nacional, sem renúncia da condição alemã. A assimilação, no caso de Lauro Müller, por exemplo, representou o acesso à rede escolar brasileira ou, mais especificamente, ao curso de engenharia da Escola Militar, mas passando primeiro pela educação étnica proporcionada por uma verdadeira "escola alemã" em Blumenau. Configura-se, então, como estratégia de ascensão social para um filho de imigrantes com residência em uma cidade portuária fora da "colônia alemã" mas nela integrada pela concentração de comerciantes teuto-brasileiros e pela proximidade geográfica. $O$ investimento escolar, até a década de 30, exigia algum grau de assimilação porque as cidades emergentes nas áreas coloniais não dispunham de escolas de segundo grau, e o acesso a um curso superior era extremamente difícil, até mesmo para legítimos luso-brasileiros (conforme as definições étnicas locais). A lém do ensino elementar, a escola era inacessível para a grande maioria dos colonos e necessária aos projetos de ascensão social das classes média e alta formadas nas vilas. Para a maioria dos colonos - integrantes de um segmento rural pouco diferenciado - a mobilidade social se apresentava quase que horizontal, traduzida no deslocamento para outras regiões coloniais de povoamento mais recente ou em uma inserção urbana no mercado de trabal ho aberto pela industrialização crescente, dentro ou na periferia das vilas de Blumenau e Brusque. Eles formavam dois segmentos distintos de trabalhadores: uma classe operária, residente na área urbana, e uma classe de agricultores de tempo parcial, que permaneceu ligada aos lotes coloniais familiares e identificada socialmente com o meio rural.

Algum grau de assimilação também se configurou como essencial na ocupação do espaço político (local e regional), pois implicava, no mínimo, o conhecimento da língua portuguesa e um relacionamento com grupos políticos externos à comunidade étnica, em grande parte resultante da atividade econômica. A ampla utilização de critérios de pertencimento étnico calcado nos ideais nacionalistas do Deutschtum, bastante intensa até a década de 30 , porém, afrontou o assimilacionismo exigido pelo nacionalismo brasileiro, que não admitia identidades "duplas". Isto é, o assimilado definido pela "germanidade brasileira" - inclusive por escrito nas publicações periódicas e na imprensa em língua alemã - não coincide com as premissas brasileiras acerca do cidadão legítimo do Estado, que condenam a existência de grupos étnicos no território nacional. M es- 
mo assim, a trajetória de Lauro M üller, para os brasileiros, só é reveladora da força assimilacionista da sociedade nacional até o momento em que sua lealdade foi posta à prova no decorrer da Primeira Guerra M undial quando a atribuição da categoria alemão adquiriu contornos de exclusão.

$\mathrm{O}$ aprendizado da língua portuguesa e outras formas de agir de acordo com o modelo brasileiro de política, como a obtenção de patentes de coronel da Guarda Nacional por quase todos os "vendeiros" importantes, ou mesmo o uso da identificação étnica menos carregado de simbolismos germânicos e sem referências raciais, permitiram o acesso a cargos eletivos, principalmente pelos comerciantes com trânsito fora das regiões coloniais.

Finalmente, a hegemonia política e econômica dos comerciantes revela o poder de articulação desse segmento como um todo, e remete a uma rede de relações sociais construída no contexto do sistema colôniavenda, estendida para fora das áreas coloniais, e que ajudou a estabelecer o controle sobre as políticas local e regional. De acordo com a historiografia local, Renaux, munido apenas de uma "carta de recomendação", integrou-se a uma rede de diversas casas de comércio pertencentes a teuto-brasileiros aparentados pelo casamento. No caso de Lauro M üller, essa evidência aparece na referência à irmã do pai, casada com um pequeno comerciante estabelecido em Blumenau. Outras histórias de vida seguem rumo semelhante, caso de Hermann Hering, por exemplo, que também trabalhou (como escriturário) para comerciantes teuto-brasileiros antes de ter sua própria "venda" e, depois, sua indústria têxtil. O detalhe da "carta de recomendação" ajuda a compor o lado laudatório da biografia de Renaux, que valoriza a ascensão social por mérito individual, mas provavelmente não foi o fator determinante na obtenção de um emprego que iniciou sua ascensão social. Tal inserção de imigrantes recém-chegados, com grau de escolaridade mais alto que a maioria dos seus empregadores, mostra que os comerciantes tinham alguma articulação com a Alemanha, em parte explicada pelas atividades de importação-exportação, que seriam intensificadas por aqueles que se engajaram na atividade industrial. Pode-se, então, falar de uma rede étnica de comércio, integrando a colônia, as vilas e a própria sociedade brasileira regional através de Itajaí e Florianópolis, e que possibilitou a ascensão social de muitos teuto-brasileiros e sua inserção na cena política brasileira. A final, Deutschtum e integração política e econômica eram coisas compatíveis desde que fosse preservada a comunidade étnica. Como ideologia, qual quer trabalho bemsucedido podia ser uma expressão da germanidade. 
Giralda Seyferth é professora do Programa de Pós-Graduação em A ntropologia Social (M useu Nacional, UFRJ) e Doutora em Ciências Humanas pela USP. Entre outras publicações, é autora dos livros A Colonização Alemã no Vale do Itajaí-M irim (2a edição, 1999), Imigração e Cultura no Brasil (1990) e Nacionalismo e Identidade Étnica (1982).

\section{Notas}

1 As circunstâncias que cercaram o estabelecimento de imigrantes em áreas coloniais não eram muito favoráveis ao pretendido desenvolvimento da agricultura fora do regime escravista. Em São Pedro de Alcântara os lotes doados a cada família foram demarcados na margem esquerda do rio $M$ aruí, no precário caminho para a vila de Lages (no planalto), em terrenos acidentados. Uma parte das 166 famílias alemãs que se destinaram ao programa de colonização deixou o lugar (cf. Cabral, 1970:207) para se fixar em Desterro, na vila de Itajaí ou no projeto colonial do baixo Itajaí-açu. As regiões escol hidas para receber imigrantes refletem os principais objetivos do sistema: ocupação do território, comunicação com o planal to e desenvolvimento de um modelo de agricultura que prescindisse do trabalho escravo.

2 Formado em química, Blumenau tinha interesse na obra de naturalistas e viajantes, especialmente de Alexander von Humboldt - tanto que outro naturalista importante, Fritz Müller, participou do empreendimento colonial, tornandose figura de destaque na política local. Antes da fundação da colônia, Blumenau esteve várias vezes no Brasil tratando da "colonização alemã" na Corte ou visitando regiões coloniais do sul a pedido da Gesellschaft zum Schutze deutcher Auswanderer - uma associação criada para defender os interesses dos imigrantes alemães. Esses poucos dados da trajetória inicial de Hermann Blumenau mostram o interesse do governo imperial brasileiro nos projetos envolvendo colonos de origem germânica.

3 A referida lei estabeleceu a compra como única forma legal de acesso à terra e, na prática, abriu espaço para a privatização do sistema de colonização em terras devolutas, com a conseqüente expulsão de ocupantes que não possuíam títulos de propriedade. A passagem do controle das terras devolutas para as províncias teve o mesmo efeito. Os governos provinciais criaram algumas colônias oficiais, mas a maior parte dos territórios do sul foi colonizada por companhias particulares (a maioria controlada por imigrantes/descendentes) que recebiam grandes concessões com o compromisso de dividi-las em lotes para venda a colonos estrangeiros. 
${ }^{4} \mathrm{~A}$ infra-estrutura necessária para tocar o empreendimento - inclusive a demarcação de lotes, abertura de vias de comunicação e propaganda para atrair imigrantes - levou a empresa de Blumenau à falência. No início de 1860, mediante contrato, o governo imperial recebeu de volta a maior parte das 20 léguas quadradas da concessão original, e os imóveis e benfeitorias da sede administrativa pertencentes à colônia. O mesmo contrato manteve Blumenau como diretor, cargo que exerceu até 1883, quando foi criado o município (cf. Silva 1972).

5 Segundo normas estabelecidas desde a Lei de Terras, os imigrantes recebiam seus lotes mediante pagamento que podia ser parcelado, e sobre essas parcelas (anuais) incidiam juros. As parcelas a pagar compunham a chamada "dívida colonial" e a elas eram acrescentados os valores dos subsídios eventualmente recebidos na chegada à colônia (quase sempre gastos com a manutenção da família antes de o lote tornar-se produtivo). Sobre os problemas relacionados à dívida colonial, ver Seyferth (1988; 1996a).

6 Indivíduos de etnia germânica figuram nas estatísticas imigratórias brasileiras como cidadãos dos impérios russo e austríaco. Assim, é difícil dimensionar a composição étnica das colônias. Willems (1946) preferiu usar o critério etno-lingüístico na configuração numérica da imigração “alemã” para o Brasil. Na verdade, apenas três grupos de imigrantes são significativos no Vale do Itajaí: alemães, italianos e poloneses.

7 Essa diferenciação, hoje, é configurada na dicotomia identitária que distingue colonos fortes e fracos. $\mathrm{N}$ a representação dos atores sociais, os primeiros são definidos como possuidores de uma colônia (lote) suficiente para a reprodução social camponesa; os segundos têm sua "fraqueza" associada à insuficiência de terras e ao trabalho assalariado (cf. Seyferth 1992).

8 Muitos alemães ocuparam o posto de diretor de colônia durante o Império. A pós a criação dos municípios, porém, os principais cargos públicos (chefe da comissão de terras, delegado, juiz etc.) e as profissões liberais eram exercidos por brasileiros, inclusive de outros estados. Eram chamados luso-brasileiros, forma "hifenada" de distingui-los dos teuto-brasileiros, situando todos na mesma categoria de cidadãos étnicos.

9 A expressão Kultur refere-se à agricultura (cultivo). Trata-se de uma associação criada em Blumenau para dar assistência técnica aos colonos. Quase todas as regiões coloniais tiveram associações semelhantes. A Kulturverein, porém, assumiu, em alguns momentos, um viés político - seus diretores estavam envolvidos também no cadastramento eleitoral dos colonos e faziam propaganda eleitoral.

100 jornal local mais comprometido com a noção de pertencimento étnico pelo jus sanguinis - que remete à idéia de uma nação alemã ampliada para englobar todos os seus membros espalhados pelo mundo, independentemente da cidadania, claramente inspirada no discurso pangermanista - em alguns momen- 
tos de acirramento político definiu M üller como "traidor" da causa teuto-brasileira. Tratava-se do jornal Der Urwal dsbote, intransigente quanto aos princípios étnicos e culturais que delimitavam a comunidade germânica no Brasil, e cuja linha editorial defendia os interesses do partido de oposição a Müller (cf. Seyferth 1994a; 1996b).

11 O sogro de Renaux integrou a primeira leva de imigrantes alemães que fundaram São Pedro de Alcântara. Permaneceu como colono e figura nas publicações comemorativas como principal "pioneiro" da imigração alemã no Vale do Itajaí. Era um colono forte (segundo a categorização atual), eventualmente definido como "verdadeiro fazendeiro". Antes do casamento, sua filha exercia o cargo de professora no ensino elementar em Blumenau — indício de que o pai era um camponês próspero, mas não um colono "enriquecido".

12 Renaux era republicano e principal empresário de Brusque em 1889 - um fato determinante para a sua entrada bem-sucedida na arena política (principalmente após os acontecimentos de 1893). A proclamação da República deixou algumas figuras importantes da política local em situação difícil, abrindo espaço para novas lideranças, habilitadas pela naturalização concedida pela Constituição.

13 Essa trajetória em cargos el etivos mostra que a atuação de Renaux não ultrapassou muito os limites do município de Brusque. Por outro lado, a candidatura de 1915 foi, claramente, uma estratégia para introduzir o filho mais velho no controle da política municipal no momento em que se retirava da vida pública para exercer o cargo honorífico de cônsul na Urheimat (pátria ancestral) carregado de significados nessa trajetória social ascendente: a principal rua da cidade, escolas, hospitais etc., receberam seu nome sempre antecedido pela identificação como cônsul.

\section{Referências Bibliográficas}

ÁLBUM DO CENTENÁRIO DE BRUSQUE. 1960. Brusque, Edição da SAB.

BUGGENHAGEN, E.A. von. 1941. História Econômica do Município de Brusque e a Obra do Cônsul Carlos Renaux. Instituto Hans Staden. Manuscrito.

CABRAL, Oswaldo R. 1970. História de Santa Catarina (2a ed.). Florianópolis: Editora Laudes.
D’AMARAL, Max T. 1950. Contribuição à História da Colonização Alemã no Vale do Itajaí. São Paulo: Instituto Hans Staden.

DUARTE, Manuel. 1917. Os Allemães em Santa Catharina. Rio de J aneiro: Tipografia do J ornal do Comércio.

ENTRES, Gottfried (ed.). 1929. Gedenkbuch zur J ahrhundertfeier deutsch- 
er Einwanderung in Santa Catharina. Florianópolis: Livraria Central. HERING, Maria Luiza Renaux. 1987. CoIonização e Indústria no Vale do Itajaí. O Modelo Catarinense de Desenvolvimento. Blumenau: Editora da FURB.

LUEBKE, Frederick C. 1987. Germans in Brazil. A Comparative History of Cultural Conflict during World War I. Baton Rouge: Louisiana State University Press.

MAMIGONIAN, Armen. 1965. “Estudo Geográfico das Indústrias de Blumenau". Revista Brasileira de Geografia, XXVII(3):389-481.

NOGUEIRA, Rui A. 1947. Nacionalização do Vale do I tajaí. Rio de J aneiro: Ministério do Exército.

OBERACKER J R., Carlos H. 1968. A Contribuição Teuta à Formação da $\mathrm{Na}$ ção Brasileira. Rio de J aneiro: Editora Presença.

RICHTER, Klaus. 1986. A Sociedade CoIonizadora Hanseática de 1897 e a Colonização do Interior de J oinville e Blumenau. Florianópolis/Blumenau: Editora da UFSC/Editora da FURB.

ROCHE, J ean. 1969. A Colonização Alemã e o Rio Grande do Sul. Porto Alegre: Editora Globo. 2 vols.

SEYFERTH, Giralda. 1974. A Colonização Alemã no Vale do Itajaí-M irim. Porto Alegre: Editora Movimento/ SAB.

.1982. Nacionalismo e I dentidade Étnica. Florianópolis: Fundação Catarinense de Cultura.

. 1988. “Colonização e Conflito: Estudo sobre 'Motins' e 'Desordens' numa Região Colonial de Santa Catarina no Século XIX". PPGAS - Comunicação, 10:1-71.

. 1992. “As Contradições da Liberdade: Análise de Representações sobre a Identidade Camponesa".
Revista Brasileira de Ciências Sociais, 7(18):78-95.

. 1994a. “Identidade Étnica, Assimilação e Cidadania: A Imigração Alemã e o Estado Brasileiro". Revista Brasileira de Ciências Sociais, 9 (26):103-122.

. 1994b. "O Incidente do Panther (Itajaí, SC, 1905): Estudo sobre Ideologias Étnicas". Antropologia Social, Comunicações do PPGAS, 4:15-80. . 1996a. “Concessão de Terras, Dívida Col onial e M obilidade". Estudos Sociedade e Cultura, 7:29-58. . 1996b. “Pluralismo, Etnia, Representação Política". In: M. Palmeira e M. Goldman (orgs.), Antropologia, Voto, Representação Política. Rio de J aneiro: Contracapa.

SILVA, J osé F. da.1972. História de Blumenau. Florianópolis: Edeme.

WAIBEL, Leo. 1958. Capítulos de Geografia Tropical e do Brasil. Rio de J aneiro: IBGE.

WILLEMS, Emilio. 1940. Assimilação e Populações Marginais no Brasil. São Paulo: Cia. Editora Nacional. . 1946. A culturação dos Alemães no Brasil. São Paulo: Cia. Editora Nacional. 


\section{Resumo}

Imigrantes alemães tiveram participação relevante no processo de colonização baseado na pequena propriedade familiar, iniciado no sul do Brasil em 1824. Nesse contexto de ocupação do território, por meio de assentamentos de famílias em regiões demarcadas como colônias, os processos de diferenciação interna e ascensão social aconteceram juntamente com a formação da identidade étnica teuto-brasileira. Os princípios distintivos dessa identidade foram baseados na especificidade cultural e social das colônias alemães e no jus sanguinis, constrastando com os imperativos de assimilação ditados pelo nacionalismo brasileiro como condição de cidadania. Este artigo aborda a questão da mobilidade social nos campos econômico e político, e as controvérsias associadas a sentimentos de etnicidade, evidenciadas em uma região de coIonização alemã em Santa Catarina (Vale do Itajaí) nas primeiras décadas da República - período inicial da industrialização a partir da atividade comercial, e de aproximação da elite teuto-brasileira com a sociedade nacional.

\section{Abstract}

German immigrants played a significant part in the process of colonization based on small family holdings, which was initiated in southern Brazil in 1824 Processes of internal differentiation and social ascension took place alongside the formation of a German-Brazilian identity, in the context of territorial occupation centered on family-settlements in colonies. The distinctive aspects of this identity were based on the social and cultural specificity of the German colonies and on jus sanguinis, which contrasts with the imperatives of assimilation dictated by Brazilian nationalism as the condition of citizenship. This article looks at the question of social mobility in economics and politics, and controversies associated with sentiments of ethnicity, as seen in an area of German colonization in the state of Santa Catarina (Vale do Itajaí) in the first decades of the Republic; a period characterized by incipient industrialization based on commercial activity, and by the approximation of the German-Brazilian elite to national society. 